\title{
Amerikan Basınında Türk-Ermeni Ortak Mandası Tartışmaları (1919-
} 1920)*

\section{Discussions about the Turkish-Armenian Common Mandate In the American Press (1919-1920)}

\author{
Prof. Dr. Sadık SARISAMAN iD 1 , Öğr. Gör. Burak ÇALIŞKAN ${ }^{(D}{ }_{2}$
}

\begin{abstract}
$\ddot{O} z$
Bu çalışmanın amacı Türkiye ve ABD arasında manda meselesine yaklaşım farkına dikkat çekmektir. Türkiye'de "Milli Mücadele döneminde manda meselesi" denildiği zaman genellikle iki husus akla gelmektedir. Bunlardan ilki Türkiye'nin bir bütün olarak ABD mandasına bırakılmasıdır. İkincisi ise ABD Başkanı Wilson'un Ermenistan'ı manda altına alma çabalarıdır. Türkiye ve Ermenistan'ın ortak mandası meselesi üzerinde yeterince durulmamıştır. Oysa Amerikan basınının meseleye yaklaşımı farklıdır. Amerikan basınındaki haber ve yorumlarda ortak manda ya da sadece Ermeni mandası söz konusu edilmiştir. Bu makalede ABD'de farklı eyaletlerde yayınlanan gazeteler çerçevesinde ortak manda sorunu derinlemesine ele alınmıştır. Böylece Amerika Birleşik Devletleri'ndeki çeşitli çevrelerin Türkiye'ye bakış açıları da gözler önüne serilmiş olacaktır. ABD basınına göre ağırlıklı olarak Türkiye'de bulunmuş olan misyonerler ve devlet adamları ortak manda fikrine destek olmuşlardır. Dikkati çeken bir husus vardır ki Ermeni asıllı ABD vatandaşlarının hiç birisi ortak mandadan yana değildir. Onların tamamı sadece Ermeni mandasını savunmuşlardır. Ortak mandaya karşı çıkanlar ise ağırlıklı olarak Ermeni asıllılardır. Ancak Ermeni olmayan $\mathrm{ABD}$ vatandaşlarının da çoğunluğunun sadece Ermeni mandasını istedikleri görülmüştür.
\end{abstract}

Anahtar Kelimeler: Ermeni, Türkiye, Amerika Birleşik Devletleri, manda, basın

Makale Türü: Derleme

\begin{abstract}
The purpose of this study is to draw attention to the different approaches to the mandate issue between Turkish and American public opinion. Two points came to mind related to "the mandate issue during the period of National Struggle" in Turkey. The first one was to leave Turkey to the American mandate as a whole. And, the second one was the efforts of the American President Wilson to mandate Armenia. However, the approach of the American press to the issue was different. Either a common mandate or only the Armenian mandate was mentioned in the news and comments of the American press. In this article, the common mandate issue is discussed within the frame of newspapers published in different states of the USA. Thus, perspectives of various circles in the USA on Turkey were also revealed. According to the American press, most of the missionaries and statesmen residing in Turkey supported the idea of common mandate. There is an issue drawing attention that none of the Armenian American citizens approved the idea of common mandate. All of them only advocated the Armenian mandate. The ones opposing to the common mandate were mostly Armenian citizens. However, it was seen that most of the USA citizens who were not Armenian supported only the Armenian mandate.
\end{abstract}

Keywords: Armenian, Turkey, the USA, mandate, press

Paper Type: Review

\footnotetext{
${ }^{*}$ Bu makale 100. Yılında Erzurum Kongresi Uluslararası Sempozyumu'nda sunulan bildirinin genişletilmiş halidir..

${ }^{1}$ Afyon Kocatepe Üniversitesi, Fen Edebiyat Fakültesi, ssadik@aku.edu.tr

${ }^{2}$ Afyon Kocatepe Üniversitesi, Eğitim Fakültesi, bcaliskan@aku.edu.tr
}

Atıf için (to cite): Sarısaman, S ve Çalışkan, B. (2019). Amerikan Basınında Türk-Ermeni Ortak Mandası Tartışmaları (1919-1920) Afyon Kocatepe Üniversitesi Sosyal Bilimler Dergisi, 21(4), 1028-1044. 


\section{Giriş}

Manda sistemi ilk defa 16 Aralık 1918 tarihinde Güney Afrika Cumhuriyeti'nden General Jean Chiristian Smuts tarafindan ortaya atılmıştır. Bilahare 1919 yılı Ocak ayında toplanan Paris Barış Konferansı gündemine taşınmıştır. 29 Haziran 1919 tarihinde imzalanan Milletler Cemiyeti Misaki'nın 22. maddesi manda ile ilgilidir. Buna göre, savaşı kaybeden devletlerden ayrılacak olan ülkelerin yönetimi kendilerini yönetme yeteneğine sahip olana kadar geçici olarak Milletler Cemiyeti'ne bırakılacaktır. Milletler Cemiyeti bu ülkeler için mandater devlet görevlendirecektir.

Görüldüğü üzere manda sistemi sömürgeciliğin hukuki zemine oturtulmuş bir şeklinden başka bir şey değildi. Dolaylı olarak galip devletlere İttifak Devletleri'nden ayrılan bölgelerin zenginliklerinden faydalanma imkânı veriyordu (Aytepe, 1999-2003: 475).

Milletler Cemiyeti Misakı'nın 22. maddesinin 4. fikrası ise doğrudan Osmanlı İmparatorluğu'ndan ayrılan ülkelerle ilgilidir (Denk, 2018). Bu fikraya istinaden Irak ve Filistin'in mandası İngiltere'ye, Suriye'nin mandası ise Fransa'ya bırakılmıştır.

Diğer taraftan İngiltere ABD'yi manda sistemine dahil etmek gayreti içerisine girdi. Osmanlı Devleti'nin mandasını teklif etti. İngiltere'nin amacı bu yolla bir kısım külfetlerden kurtulmaktı. Türkiye'de bulundurmak zorunda olduğu askerlerini geri çekerek ağır mali yükü üzerinden atacaktı. İran'daki petrolleri, Mezopotamya'daki potansiyel rezervleri hiçbir bedel ödemeden korunacaktı. Ortadoğu'daki Fransız nüfuzunun önüne geçilecek, Rusya'daki Bolşevik idareye karşı da bir tampon bölge oluşacaktı. İlaveten Pantürkizm'in canlanması engellenecekti (Aytepe, 1999-2003: 476).

Söz konusu teklif ABD Başkanı Wilson'un ilgisini çekti. Ancak, Wilson karar vermeden önce mahallinde incelemeler yaptırmak istedi (İlter, 2001:303). Bu amaçla bir kurul oluşturulmasına karar verildi.

Nihayetinde General Harbord 46 kişiden oluşan bir heyet oluşturdu. Paris'ten yola çikan heyet 2 Eylül 1919 tarihinde İstanbul'a geldi. Bilahare Anadolu'da ve Kafkaslarda incelemelerde bulundu. Sivas, Erzincan, Erzurum, Erivan, Tiflis, Bakü ve Batum başta olmak üzere çok sayıda şehir ve yerleşim birimini ziyaret etti (Akgün, 1981) Diğer taraftan Türkiye'de de Amerikan mandasını çözüm olarak görenler vardı. Bu hususta başı çeken Wilson Prensipleri Cemiyeti idi. Dönemin birçok aydını da ABD mandasını ülke bütünlügünü korumak ve ekonomik açıdan kalkınmanın bir aracı olarak gördüler (Ayışığı, 2004)

Bütün bu gelişmelerle bağlantılı olarak General Harbord manda konusunda bir rapor hazırlamıştır. Bu raporda mandayı kabul etmenin ABD'ye büyük külfetler getireceği sonucuna varılmıştır. Özellikle sadece Ermenilere yönelik kurulacak bir mandanın kesinlikle kabul edilmemesi yönünde görüş bildirmiştir (Akgün, 1981: 133-151).

$\mathrm{Bu}$ arada Harbord'un raporundan bir ay sonra, Amerikan Senatosu Versay Antlaşması'nı ve 19 Kasım 1919 tarihinde de Milletler Cemiyeti Paktı'nı onaylamayı reddetmiştir (Gürbüz, 2002). Böylece ABD'nin manda yöntemi kurması gerçekte imkânsız hale gelmiştir. Çünkü manda rejimleri Milletler Cemiyeti'ne bağli bir sistemdi.

Diğer taraftan Başkan Wilson Ermenistan mandası konusunda 1srarlı idi. O, 24 Mayıs 1920 tarihinde Ermenistan üzerine kurulacak olan manda idaresinin kabul edilmesi için Senato'dan onay istedi. Wilson, Kongre'ye manda idaresinin onayı için göndermiş olduğu iki sayfalık mesajında özellikle Hıristiyan dayanışmasını öne çıkartmış ve mesajının hemen her paragrafinda Hıristiyanlığı referans olarak kullanarak kongre onayını garanti altına almayı amaçlamıştı. Ermeni lobisi de kendisini yoğun bir şekilde desteklemiştir. Gazetelerde "manda kabul edilmezse Hiristiyan Ermeni ulusunun yok olacă̆l " ilan edilmiştir. 
Buna rağmen Amerikan Senatosu 1 Haziran 1920 tarihinde Ermeni mandasını 23’e karş1 52 oyla reddetti. 12 Demokrat ve 11 Cumhuriyetçi Senatör evet oyu verirken, 52 Senatör hayır oyu kullanmıştır (Köse, 2014: 210).

$\mathrm{Bu}$ çalışmanın amacı manda meselesinin ABD basınına yansımasını açık ve objektif bir şekilde ortaya koymaktır. Türkiye'de ABD basınını da kullanan araştırma sayısı çoktur. Ancak ABD basınını merkeze koyarak ortak manda meselesini tartışan hiçbir araştırma mevcut değildir. $\mathrm{Bu}$ sebeple makale özellikle "ortak manda" terimini literatüre kazandırmak ve söz konusu eksikliği gidermeyi amaçlamaktadır.

Araştırmanın kapsamı sadece ABD basınındaki Türkiye ortak manda tartışmaları ile sınırlıdır. Ermenistan mandası veya diğer manda tartışmaları araştırmanın konusuna girmemektedir. Ayrıca ABD basını dışındaki her türlü manda tartışmaları da araştırmanın kapsamı dışındadır.

Araştırma basında ortak manda meselesi ile sınırlı olduğundan dolayı temel kaynaklar dönemin Amerikan gazetelerinden oluşmaktadır. ABD'deki çeşitli eyaletlerde yayınlanmış olan gazetelerden yararlanılmıştır. ABD arşiv belgelerinden ve diğer kaynaklardan yararlanma konusunda özel bir gayret gösterilmemiştir.

\section{Türk-Ermeni Ortak Mandasını Destekleyenler}

Amerikan basınında manda meselesi yoğun olarak tartışılmıştır. Türk-Ermeni ortak mandasına yönelik çok sayıda haber ve yazı kaleme alınmıştır. Bu konuda görüş bildiren ve yazı yazanların büyük çoğunluğu Ermeni asıllıdır. Ermeni olmayan bazı Amerikalılar da tartışmaya katılmışlardır.

Türk-Ermeni ortak mandasını savunanların başında Robert Koleji Müdürü Dr. Caleb Gates $^{3}$ gelmektedir. O, New York Times gazetesinde teferruatlı bir şekilde görüşlerini dile getirmiştir. Buna göre Gates Amerika'nın tüm Osmanlı İmparatorluğu üzerinde manda yönetimi kurmas1 gerektiği görüşünü savunmuştur. Türk-Ermeni ortak mandasını önermiş, sadece Ermeniler için Amerikan Mandası fikrine karşı çıkmıştır. Gates, yalnız Ermenilere yönelik bir manda yönetimi kurulacaksa İngiltere'nin mandater olmasının daha mantıklı olacağını ifade etmiştir. Ona göre Mezopotamya'yı mandası altına alan İngiltere'nin yanı başındaki "Ermeni Devleti" üzerinde de manda yönetimi kurması doğru olanıdır.

Ona göre Amerika Birleşik Devletleri sadece Ermeni Devleti üzerinde manda yönetimi kurarsa ciddi sorunlarla karşı karşıya kalacaktır. Bu sorunlardan ilki Ermenilerin yurt kurmak için önerdikleri devletin sınırlarının abartılı olmasıdır. Zira Ermeniler "Mantı̆̆a sığmayan aşırı isteklerde" bulunmaktadırlar. İkinci olarak Türkler yanı başlarındaki Ermenilerin manda yönetimi sayesinde gelişip kalkındıklarını görecekler ve kendileri ile kıyaslayarak dünyadan ve batılılardan nefret eder hale geleceklerdir. Bu durum Amerika için sıkıntı yaratacaktır. Çünkü halinden memnun olmayan Müslüman kesim milyonlarca nüfusu ile ciddi bir tehdit oluşturacaktır.

Gates, Amerika Birleşik Devletleri'nin Türkiye'nin genelini dışarıda tutarak sadece İstanbul üzerinde manda yönetimi kurması gerektiği görüşünü de eleştirmiştir. Ona göre böyle bir karar daha büyük sorunlar yaratacaktır. Zira Amerikan mandası altındaki İstanbul ve Ermenistan dışında kalan Anadolu toprakları karışıklığa mahkûm edilmiş olacaktır. İstanbul manda yönetimi bölgesinde yaşayan insanlar Türkiye'nin diğer bölgeleri ile kader ortaklığı duygusu taşımayacaklardır. Bu da Amerika için sorun oluşturacaktır.

${ }^{3}$ Caleb Frank Gates (1859-1946), Robert Koleji'nin müdürlüğünü yapmış bir misyonerdir. 18 Ekim 1859'da Chikago'da doğmuştur. İlk dini eğitimini babası Calep Foote Gates'den almıştır. 1866'da Wheaton College'den ve 1877'de ise Beloit College'den mezun olmuştur. İstanbul'daki Robert College'in üçüncü müdürlügünü yapmıştır. Bu görevini 1903-1932 yılları arasında sürdürmüştür. (American National Biography,2018) 
Diğer taraftan Caleb Gates "Ermeni Devleti” kurmanın güçlüklerine de işaret etmiştir. Ona göre Ermenistan için birinci sorun nüfus yetersizliğidir. Tüm Ermenilerin kendi yurtlarına dönmek istediklerinde dahi sayıları 1.000.000'u geçmeyecektir. Oysa bu bölgede yaklaşık 3-4 milyon Türk ve Kürt bulunmaktadır. Ermeniler ezici çoğunluğu oluşturan Türk ve Kürtlerle beraber yaşamak zorunda kalacaklar, bu da ciddi problemlere yol açacaktır. Bu yüzden Türkiye'nin bölünmesi Amerika için ölümcül bir hata olacaktır.

Robert Koleji Müdürü Gates, 1919 yılı Şubat ayından itibaren Ermeni mandası ile ilgili koşulların daha da güçleştiğini ifade etmiştir. $\mathrm{O}$, bu durumun Avrupalı Devletlerin manda yönetimi ile ilgili ortak bir karar almasını zorlaştırdığını düşünmektedir. Ona göre en ciddi hatayı Kilikya'daki Adana'yı işgal eden Fransa yapmıştır. Ermenilere Fransız üniformaları giydirmişler ${ }^{4}$ ve Türkler de doğal olarak İtilaf Devletleri'nin kendilerine kuvvet uygulayacaklarını düşünmüşlerdir. Bunun sonucu Türklerin silahlanması olmuştur.

Onun ifadesiyle Ermenilerin Kafkasya'daki mevcut durumu ise içler acısıdır. Kafkaslarda 350.000 Ermeni yaşamaktadır. Bunlar son derece kötü şartlarda, açlık ve sefaletten kırılmaktadırlar. Türkiye'den göç etmiş olan Ermenilerin evlerine dönmeleri mümkün değildir. Çünkü gelecekleri bölgelerde güvenlik sorunu vardır ve korumasızdırlar. Bu durumda kendi yurtlarına dönemeyen Ermeniler üretici hale getirilemeyecekler ve tekrar açlık sorunu yaşayacaklardır.

Dr. Gates, açıklamalarında Birinci Dünya Savaşı sırasında Robert Kolejini kapattırmamaya yönelik verdiği mücadeleye de değinmiştir. Savaş boyunca kolejin zor şartlarda faaliyet gösterdiğini, Almanların ve Türklerin defalarca Kolej binasını askeri amaçlar için kullanmak istediklerini ifade etmiştir. Beş kere farklı nedenlerle Türk askerlerinin Robert Kolejini işgal etmek için geldiğini söyleyen Dr. Gates, durumu Talat Paşa'ya aktardığında askerlerin geri çekildiğini vurgulamıştır. Gates, Talat Paşa'nın kendisine Amerika Birleşik Devletleri Osmanlı Devleti'ne savaş ilan etmediği sürece okula dokunmama garantisi verdiğini açıklamıştır (New York Times, 4 Haziran 1919: 23)

Gates'in görüşleri 29 Haziran 1919 tarihli New York Times gazetesinde de yer almıştır. Buna göre Anadolu'da bağımsız Türk yönetiminin devam etmesi halinde diğer milletler huzur bulamayacaklardır. Türk hükümetine kendi topraklarının tamamı üzerinde mutlak yönetim hakkı verilmemelidir. Bu durum huzursuzluk ve kargaşaya yol açar. Türklerin başkentinin İstanbul veya batı Anadolu'da bir yer olmasının hiçbir önemi yoktur. Ermenistan da bu huzursuzluktan payını alacaktır Milletler Cemiyeti veya herhangi bir devlet Türk yönetimini manda ile kontrol altına almalıdır. Bu olmazsa Türk sorunu uluslararası bir sıkıntı olmaya devam edecektir.

Aynı şekilde sadece Ermenistan veya İstanbul üzerinde manda yönetimi kurulması sorunu kesinlikle çözmeyecektir. İstanbul üzerinde kurulacak bir manda yönetimi Türkleri Avrupa'da bırakacak ve sorunların devamına yol açacaktır. Hıristiyan uygarlığı için Batı Anadolu mutlaka kontrol altına alınmalıdır. Bunun için tek çözüm tüm Türkiye üzerinde manda yönetimi kurulması olacaktır.

Gates, Ermeniler için de tek kurtuluşun Amerika Birleşik Devletleri'nin tüm Anadolu üzerinde bir manda yönetimi kurması olduğunu ifade etmiştir. Zira ona göre Ermenilere ne kadar geniş topraklar verilirse verilsin veya istekleri ne ölçüde karşılanırsa karşılansın tek başlarına hayatlarını sürdürmeleri imkânsızdır. Çünkü sahip olacakları her bölgede Türkler ve Kürtlerle beraber yaşayacaklardır. Türklerin nüfusu Hıristiyanların dört katı olacaktır.

Türklerin Amerikalılara saygı duymaları ve onları iyi niyetli olarak görmeleri de ABD'nin işini kolaylaştıracaktır. Ancak bilinmelidir ki hem Ermenistan'ı desteklemek hem de Türkleri kucaklamak oldukça zor bir iştir. Manda yönetimini üstlenecek ülkenin mutlaka Ermenistan ve Kafkaslarda yardım faaliyetleri yürütmesi gerekir. Bu sadece özel fonlarla başarılabilecek bir iş değildir. 30.000.000 dolarlık bir fon bile ihtiyacı karşılamak için yeterli gelmeyecektir.

\footnotetext{
${ }^{4}$ Türk kaynakları da bu durumu doğrulamaktadır. Bkz. Yaşar Akbıyık, 1999.
} 
Kafkaslardaki yardım faaliyetlerinin devamı için aylık 1.000 .000 dolar gereklidir. Bütün bu sebeplerden dolayı Amerika Birleşik Devletleri Ermenistan'ı ve tüm Anadolu'yu içine alan bir manda yönetimi kurmalıdır. Çünkü ancak Birleşik Devletler bu maddi yükümlülüğü karşılayabilir. En kısa sürede Amerika Birleşik Devletleri Ermenistan'1 da içine alacak şekilde tüm Anadolu’yu manda yönetimine aldığını ilan etmelidir.

Eğer sadece Ermeni mandası kurulacaksa bu iş için en uygun ülke İngiltere'dir. Çünkü İngilizler manda yönetimini kabul ederlerse, bu yönetim onların kontrollerindeki Mezopotamya'ya da komşu olacaktır. Bilindiği üzere İngiltere Mezopotamya'da mükemmel bir yönetim kurmuştur. Sir William Wilcox, Mezoptamya'da sulama projeleri üzerinde çalışmaktadır. Bu coğrafya çok kısa sürede Nil bölgesine benzetilecektir. Avrupa tahıl ihtiyacını buradan karşılayacaktır. İngiltere, Türkiye'nin bütünü üzerinde manda yönetimine taraftar görünmemektedir. Sadece İstanbul üzerindeki bir manda yönetimi İngilizlerin tercihidir. Çünkü Sultan'ın Halifelik gücünün alınması onların en önemli hedefleridir. İngiltere açısından bu gerçekleşirse Hindistan'daki ve Afrika'daki milyonlarca Müslüman harekete geçirilemeyecektir. Ancak bu abartılı bir yaklaşımdır. Çünkü Dünya Savaşı sırasında bile Müslüman liderler bir cihat başlatamamışlardır (New York Times, 29 Haziran 1919: 23)

Harput'daki Amerikan kolejinde görev yapan misyoner Henry Riggs ${ }^{5}$ de Ermeni sorunu ile ilgili görüşlerini Amerikan basını aracılığıyla paylaşmıştır. O, 14 Ekim 1919 tarihli demecinde bundan altı ay öncesine kadar bağımsız Ermenistan'a inandığını, fakat bugün geçekleşmesinin imkânsız olduğunu gördügünü ifade etmiştir. Ona göre Osmanlı topraklarından geriye kalan bölgelerde tek ve ortak bir manda yönetimi kurulmalıdır. Bunun gerçekleşmesi için aklı selim Ermeniler çaba göstermelidir. Tek ve yeni bir Ermenistan kurulursa çoğunluğu oluşturan Türklerle ırksal problemler yaşanabilir. Ayrıca Ermeniler eski hatalarına devam ederek öç alma duygusu ile hareket edebilirler (The Washington Star, 14 Ekim 1919. 22).

Ortak manda fikrini savunanlardan birisi de Djevad Eyour'dur. Eyour, Newyork Times'de "Ortadoğu'da Amerika 'nın Avantajları" başlıklı yazısında ortak manda yönetimine olan inancını dile getirmiştir. Ona göre Başkan Wilson'un Avrupa'yı ziyareti sırasında Ermeni mandası kabul edilseydi, Osmanlı Devleti'nin 1914 sınırları içinde ortak manda yönetimi üstü örtülü bir şekilde gerçekleşebilirdi. Bu yönetimi Türkler, Ermeniler ve Rumlar da desteklerdi. Dünyanın en ilginç bölgelerinden birinde böyle bir yönetim Amerika'ya olağanüstü firsatlar sağlayabilirdi. Zira Anadolu önemli limanları, doğal kaynaklarının zenginliği ve inanılmaz potansiyeli ile Amerika için yeni aç1lımlar getirebilirdi. (Eyour, 1922: 15).

ABD'nin eski İstanbul Büyükelçi Henry Morgenthau ${ }^{6}$ da Amerika'nın İstanbul, Anadolu ve Ermenistan'1 içine alan manda yönetimi kurması gerektiği görüşünü savunmuştur. Ancak Amerika'daki Ermeniler ortak manda yönetiminin Ermenistan üzerinde Türk baskısını arttıracağı gerekçesiyle karşı çıkmışlardır (The Detroit Free Press, 25 Mayıs 1919: 1).

25 Aralık 1919 tarihli bir haberde de ortak manda projesi desteklenmiştir. Haberde Henry Morgenthau liderliğindeki Amerikalıların yapması gereken ilk işin Türklerden İstanbul'un yönetimini almak olduğu belirtilmiştir. Türk idaresinin Hıristiyanlara, Hıristiyanların yönetiminin de Türklere adalet getirmeyeceği ve sonu gelmez savaşların kaynağ 1 olacağı uyarısında bulunulmuştur.

\footnotetext{
${ }^{5}$ Sivas doğumludur. Amerika'da 1896 yılında Carleton Koleji'nde eğitim almış, daha sonra Harput’a dönerek Harput Koleji'nin $1902-$ 1910 yılları arasında müdürlüğünü yapmıştır Döneminde Harput Koleji sanat atölyeleri kurularak genişlemiştir. Riggs, Osmanlı memurları ve aydınları ile iyi ilişkiler kurarak, Harput'da önemli bir yer edinmiştir. (Kılıç, 2007: 480)

${ }^{6}$ Henry Morgenthau 1913-1916 Yılları arasında İstanbul'da Amerikan büyükelçiliği yapmıştır. Yahudi bir aileden gelmektedir. Amerika'da hukuk eğitimi almıştır. New York'da emlak komisyonculuğu yaparak ünlenen Morgenthau, Başkan Wilson'un 1912'deki başkanlık seçimleri sırasında Demokrat Partinin mali komite başkanı olarak görev almıştır. 1916 yılında kaleme aldığı "Büyükelçi Morgenthau'nun Öyküsü” kitabı sözde Ermeni soykırımını anlatan bir referans kitap olarak kullanılmıştır. (Morgenthau, 2003: xxvxxxvii).
} 
Habere göre farklı kabileler, dinler ve fraksiyonların tümü Amerika Birleşik Devletleri'ne güven duyuyorlar ve Ermeni mandasını kabul edecek tek devlet olarak görüyorlar. Amerika'nın tüm ırklara ve dinsel guruplara sağladığı adalet, onlara yönelik uygulanacak mezalimin engelleneceği güvenini veriyor. Müslümanların Hıristiyanlara veya Hıristiyanların Müslümanlara yönelik mezalimi de Amerikan adaleti ile önlenecektir (The National Tribune, 25 Aralık 1919. 1)

Basına Amerika'nın bazı çekincelerinden dolayı Ermeni ve Türk mandasını kabul etmeyeceğine ilişkin haberler de yansımıştır. İstanbul, Anadolu ve Ermenistan'1 kapsayan bir manda yönetiminin bölgesel bütünlügünün sağlanmasının güçlükleri üzerinde durulmuştur.

Öte yandan manda meselesi ile ilgili Türk gazetelerine yansıyan bazı haberler de Amerikan basınında kullanılmıştır. Vakit gazetesine dayandırılan bir habere göre Türkler Başkan Wilson'un rahatsızlığının kendileri için bir felaket olduğunu düşünmektedirler. Onlar Amerikan başkanının Osmanlı Devleti'nin toprak bütünlügünün korunmasına destek vereceğine inanmışlardır.

Haberde gemi taşımacılı̆̆ıyla uğraşan İtalyan Pietro Rizzo'nun Türk mandası ile ilgili görüşlerine de yer verilmiştir. Kaptan, Amerika Birleşik Devletleri'nin Türk mandasını kabul etmesi durumunda bunun Türkler için harika olacağını düşünmektedir. Küba'nın İspanyol savaşları sırasındaki sefaletini gördüğünü vurgulayan kaptan Rizzo, Amerikalılar adayı temizledikten sonra Küba'nın gece ve gündüz kadar değiştiğini vurgulamıştır. Benzer durumun Türkiye'de de yaşanabileceğini ifade etmiş̧ir (The Washington Star, 29 Ekim 1919: s.19)

Chicago Üniversitesi Rektörü Harry Pratt da ortak manda fikrini savunanlardandır. Pratt, 1918 yılında American-Persian Relief Komisyonu'nun direktörü olarak İran'da görev yapmıştı. O, görüşünü Ermeni mandasını merkeze oturtarak açıklamıştır. Ona göre kurulması planlanan Ermeni mandasının içine İstanbul, boğazlar ve Türklerden kalan bölgeler de dahil edilmelidir. Bu sayede dünya barışına katkı sağlanmış olacaktır.

Rektör Harry Pratt, Ermenistan'ın başarılı olabilmesi için mutlaka bir dış güce ihtiyacı olduğunu özellikle vurgulamıştır. Ermenistan için bir orduya ve maddi desteğe ihtiyaç duyulduğunu belirtmiştir. Güvenlik ve ekonomi açısından da demiryolu hattının inşa edilmesinin gerekliliğine işaret etmiştir. Ermenistan'ın eğitim kurumlarının derhal inşa edilmesi ve düzenlenmesi için Amerikalı misyonerlerin sorumluluk almaları gerektiğini belirtmiştir.

Harry Pratt'a göre Ermeniler yetenekli insanlardır. Onlara kendilerine ait bir toprak parçası üzerinde öz yönetim fırsatı verilmemiştir. Ermenilere dostça bir rehberlik sağlanırsa her türlü zorluğun üstesinden gelebilirler (The Christian Science Monitor, 20 Mart 1920: 4)

Bunların dışında Amerika Birleşik Devletleri eski başkanlarından William Howard Taft, Amerikalı Misyoner Liderlerinden Dr. William Westermann ve James Barton ${ }^{7}$ da ortak manda fikrine savunmuşlardı. Ancak basında bu kişilerin konu ile ilgili demeç ve yazılarına rastlanılmamıştır (Karacagil, 2015: 103).

\section{Türk-Ermeni Ortak Mandasına Karşı Çıkanlar}

Türk-Ermeni ortak mandasına karşı eleştiriler genellikle Ermeni kökenli kişilerden gelmiştir. Bunlardan Arshag Mahdesian ${ }^{8}$, Osmanlı Devleti'nin bütünlüğünden yana görüş bildiren Robert Koleji müdürü Caleb F. Gates'e cevaben bir yazı da kaleme almıştır. Bu yazı New York Times'ın 8 Haziran 1919 tarihli baskısında yayınlamıştır. Burada Mahdesian, Gates ve onun gibi "Türk hayranları"nın, mütarekeden hemen sonra Amerikan Dışişleri Bakanlığı'nın

\footnotetext{
7 The American Comitee for Armenian and Syrian Relief başkanı ve Amerikan Board'un dış ilişkiler sekreteri. ( The Boston Daily Globe, 6 Mart 1918: 8).

${ }^{8}$ New York'un tanınmış Ermenilerindendir. The New Armenia dergisinin editörlüğünü yapmıştır. Yale Üniversitesinde İngiliz Edebiyatı eğitimi almıştır. Şair, yazar ve gazetecidir. İngilizce yayın yapan Ermeni dergileri yayınlayarak Ermeni propagandasını yürütmüştür. (Mahdesian, 1917: 448-466).
} 
hazırladığı ve Amerikan misyonerlerinin etkisi ile oluşan bir rapordan etkilendiklerini iddia etmiştir.

Mahdesian, Gates'in Ermeni Devleti'nin kurulmasının ciddi zorluklar içerdiği, Fransızların Kilikya'da Ermeni birliklerini kullanmalarının Türklerin silahlanmalarında ve Ermenilere yönelik nefretin oluşmasında etkili olduğu yönündeki görüşlerini eleştirmiştir. $O$, Ermenilerin tarih boyunca Hıristiyan dünyaya yaptıkları hizmetlere dikkati çekerek Türklerin işgallerine karşı direndiklerini ve müttefiklerle iş birliği içerisinde çalıştıklarını hatırlatmıştır. Ermenilerin bu hizmetlerinin mutlaka göz önünde tutulması lazım geldiğini bildirmiştir.

Mahdesian'a göre Ermeni mandasının araştırılması amacıyla kurulan komisyonda yer alan Fransız, İngiliz ve İtalyan temsilciler de Ermenileri haklı bularak Osmanlı yönetimindeki azınlıklara bağımsızlık verilmesini önermişlerdir. Bu sebeplerden dolayı Ermenilere bağımsızlık verilmesi bir lütuf değildir. Onlara uygulanan "Bask ve kötü muamele, acı ve vahşet ile 19151916 Soykırımı" karşılığında adaletin bir gereğidir. Türk Hükümeti ve onların dostları ise, "Türk Ermenistanı"nda hiçbir Ermeni kalmadığını iddia etmektedirler. Bu iddialar da asılsızdır (Mahdesian, 1919: 36).

Arshag Mahdesian yaklaşık bir ay sonra manda konusunu ele alan başka bir yazı daha kaleme almıştır. $\mathrm{O}$, bu yazısında da Türklerin manda yönetimine dahil edilmemesi gerektiği görüşünü savunmuştur. Ona göre Amerikalılar sadece Ermeni mandasını kabul etmelidirler. Mahdesian'ın ifadesiyle "Türkler hastadır". Karakter itibarıla yönetme yeteneğinden yoksundurlar. Misyonerlerin Türkleri kazanma çabası boşunadır. 60 yıllık misyonerlik tarihinde Misyonerler hiçbir Türk’ü Hıristiyan yapamamıştır. Türkiye'deki uluslar içinde "en üstün olanlar" ise Ermenilerdir.

Diğer taraftan Mahdesian'ın ifadesine göre Türkler Amerikan mandasına sicak bakmaktadır. Oysa Amerika Birleşik Devletleri Türklerin de dâhil olacağı manda yönetimini istememelidir. Çünkü Türklerin demokrasiden haberi yoktur. Onlar "Muhammed̂̀", yani Müslüman oldukları için teokratik bir yaşam sürmektedirler. Çok eşli aile yapıları vardır ve Amerikalıların onları tek eşli yapmak konusunda çok fazla çaba sarf etmeleri gerekecektir. Amerikalıların Türkleri, Türklerin de Amerikalıları ve psikolojilerini anlamaları imkânsızdır. Türkler için en uygun mandater devlet İran'dır. İranlılar Türkleri, Türkler de İranlıları kolayca anlayabilirler. Bununla birlikte Ermeniler de Amerikalılar ile iyi anlaşabilirler, bu iki toplumun entelektüel seviyeleri birbirlerine çok yakındır (Boston Daily Globe: 7 Ağustos 1919: 11).

Mahdesian birkaç gün sonra başka bir gazeteye verdiği demeçte de Türklere manda yönetimi için en uygun ülkenin İran olduğu görüşünü yenilemiştir. Ona göre Türklerin "kimseyi taciz edemeyecekleri" ş̧ekilde Anadolu'nun bir bölgesine yerleştirilmeleri şarttır. Türklerin ve Ermenilerin milli kalkınmalarını sağlayabilmeleri için mutlaka birbirinden ayrılmaları gerekir.

Diğer taraftan Mahdesian, aynı yazısında Türkleri medeni dünyaya hiçbir katkıları olmayan saldırgan bir millet olarak da tanımlamıştır. ABD'nin Türkiye üzerinde manda yönetimi kurabilmek için Türklerin "işgalci dürtülerini” kontrol etmek zorunda kalacağını vurgulamıştır. Mahdesian Türklerin manda dolayısıyla maddi kazanç elde etmek peşinde koştukları eleştirisinde de bulunmuştur. Ona göre bir Türk yetkilinin Paris'de Christian Science Monitor muhabirine verdiği demeçteki "Biz Amerikan mandasına girdiğimizde demiryolları, para ve maddi kazanç sağlayacağız” sözleri bu iddiayı doğrulamaktadır (The Christian Science Monitor, 11 Ağustos 1919: 11)

Görüldüğü üzere Arshag Mahdesian ABD'nin farklı eyaletlerindeki gazetelerde görüşlerini dile getirerek mümkün olduğu kadar daha fazla Amerikan vatandaşını etkilemeye çalışmıştır. Bunlardan New York Times, New York eyaletinde yayınlanırken The Christian Science Monitor ve Boston Daily Globe gazeteleri Massachusetts eyaletinin Boston şehrinde basilmaktayd. 
Türk-Ermeni ortak mandasına karșı çıkan Ermeni yazarlardan birisi de Vahan Cardashian'dır". Cardashian "Amerika Neden Ermeni Mandasını Kabul etmeli" başlıklı bir kitapçık hazırlamıştır. Bu kitapçığın içeriği Amerikan basın organlarına yansımıştır. Cardashian kitabında Ermeni Devleti olarak planlanan topraklarda yaşayan diğer milletlerin kendi ülkelerine gönderilmesi gerektiği görüşünü savunmuştur. Ona göre Türkler Türkiye'ye, Gürcüler Gürcistan'a, Tatarlar Tataristan'a, İranlılar İran'a gönderilmelidir. Buna karşılık dünyanın çeşitli yerlerinde yaşayan 1.000.000 Ermeni de kurulacak olan Ermenistan Devleti'ne yerleştirilmelidir (The New York Times, 1 Haziran 1919: 38).

Cardashian, New York Times'de yayınlanan bir beyanatında da "ortak manda" konusundaki görüşlerini açıklamaya devam etmiştir. O, beyanatında Ermenistan, Anadolu ve İstanbul'u da kapsayan ortak bir Amerikan manda yönetimi kurulması tasarısına tepki göstermiş, bunun "kasap ile kuzunun" bir arada yaşaması anlamına geleceğini ifade etmiştir. Ona göre bu tasarı aslında Türklere aittir. Henry Morgenthau, Robert Koleji'nden Caleb Gates tarafindan da desteklenmektedir. Mr.Morgenthau'nun “Türk yönetiminin bütünlüğünü" savunan projeye destek vermesinin nedeni tamamen kişisel hırsları ile ilgilidir. Türkler ise ortak manda yönetimi adı altında "Ermenistan topraklarını" ellerinde tutmak istemektedirler. Türklerin bu oyunu bir yere kadar anlaş1labilir. Fakat üzücü olan Mr. Morgethau ve Dr. Gates'in tutumudur. Bu yaklaşım Amerikan karşıtıdır. Zira tasarı hayata geçerse Türkler, Ermeniler üzerinde işledikleri suçlar nedeni ile ödüllendirilmiş olacaklardır. Buna karşılık, Ermeniler inançları ve Amerika'ya sadakatleri nedeniyle cezalandırılacaklardır.

Mahdesian'ın beyanatında yer alan diğer görüşleri ise şöyledir;

Amerikan mandasının İstanbul ve Anadolu'yu kapsaması ABD'nin üstesinden gelemeyeceği tehlikeli bir durum oluşturacaktır. İstanbul Avrupa'nın "kumpas ve entrika" merkezidir. Mandaya dahil edilirse ABD burada büyük bir ordu bulundurmak durumundadır. Ayrıca burada idaresini kuvvetlendirmek için uzun ve belirsiz bir süre kalmak zorunda olacaktır.

Anadolu'da kurulacak Amerikan mandası da sorunlu olacaktır. Çünkü Türk nesli kendi kendini yönetmekten ve modern uygarlığın etkilerinden çok uzaktır. Birkaç Amerikalının kişisel hırsları yüzünden ABD kendini kaos ve karmaşa ortamına atmamalıdır.

Herhangi bir kimsenin son 600 yıllık Ermeni -Türk ilişkilerine baktığında neden iki ırkın bir arada yaşayamayacağını anlaması zor değildir. Ona göre Türkler ile Ermenilerin hiçbir ortak yanı yoktur. İnanç, dil, moral değerler, gelenekler, idealler anlamında iki toplum çok farklıdır. Ortak manda tasarısı bu yüzden gerçekleştirilemez.

Amerikan halkı da Ermeni ve Türklerin uzlaşabileceği fikrine uzaktır. Amerikan toplumu "kasapla kuzunun bir arada yaşamasını" görmek istemeyecektir. Türkler kendilerini manda yönetimine aldırmak istiyorlarsa Amerika' dan daha büyük midesi olan bir ülke bulmalıdırlar (The New York Times, 3 Haziran 1919: 12)

Cardashian, Dr. Gates'in basina yansiyan “Amerika, Ermenistan, Anadolu ve İstanbul'un dâhil olduğu ortak bir mandayı kabul etmelidir. Ermeni devletine gelen Ermeniler 1.000.000 olmayacaktır. Onlarla beraber 3.000.000 veya 4.000.000 Türk ve Kürt de olacaktır” iddiasına karşı bir açıklama yapmıştır. Ona göre 1913'de Türk Ermenistan'ının nüfusu 3.100.000'dür. Bu nüfusun 1.425.000'i Ermeni'dir. Diğerleri Türkler, Kürtler ve diğer milletlerdir ${ }^{10}$. Türklerin

\footnotetext{
9 Vahan Cardashian 1883 yılında Kayseri'de doğumludur. Kayseri'de tahsil hayatına başlamış, 1902 yılında Amerika Birleşik Devletleri'ne yerleşmiştir. Yale Üniversitesinde 1904 'de başladığı hukuk öğrenimini 1908'de tamamlamıştır. Aynı yıl ABD vatandaşı olmuştur. Armenian Press Bureau (Ermeni Basın Bürosu)'nun başına geçmiștir. Basın Bürosu, 1918- 1922 tarihleri arasında Türk aleyhtarı ve bağımsız Ermenistan'ın kurulmasına yönelik yoğun propaganda faaliyetlerinde bulunmuştur. Cardashian, Aralık 1918 tarihinde "American Committee for The Independence of Armenia” (Ermenistan'ın Bağımsılı̆ğı için Amerikan Komitesi)'ni kurdu. Komitenin başkanlığına, 1917 senesine kadar Amerika Birleşik Devletleri'nin Almanya Büyükelçiliği’ni yapmış ve Amerikan bürokrasisini iyi bilen bir isim olan James Watson Gerard'1 getirildi. 12 Haziran 1934'de kalp krizi sonucu ölünceye kadar her firsatta Türk ve Türkiye aleyhtarı faaliyetlerine devam etmiştir Vahan Cardashian hakkında daha geniş bilgi için bkz. (Karacagil, 2015).

${ }^{10}$ Görüldüğü üzere Cardashian bile Ermenistan olarak adlandırdığı Türkiye topraklarında Ermeni nüfusunun azınlıkta olduğunu kabul etmiştir.
} 
Ermenilerin yarısını ortadan kaldırdığ̣ düşünülürse şu an hayatta kalanların sayısı 1.000.000'dur. Ermeni nüfusunun azalma nedeni Türklerin barbarlığıdır.

O açıklamasında nüfus meselesi ile alakalı olarak Ermeni Milli Delegasyonunun hazırlamış olduğu istatistiklere de yer vermiştir. Buna göre "Ermeni devleti" içinde yaşayan Türkler, Tatarlar ve Kürtlerin nüfusu 1.000.000'u geçmemektedir. Bölgedeki Ermenilerin sayıs1 en az 2.500.000'dir (The New York Times, 5 Haziran 1919: 12). Görüldügü üzere Cardashina'ın Ermeni nüfusu hakkında verdiği bilgiler birbirini tutmamaktadır.

Cardashian Türklerin doğaları ve ırki yapıları gereği olarak zararlı ve yıkıcı olduğu iddiasındadır. O, Türkler için "Türkler içgüdüsel olarak yıkıcıdır”, "yağmalar, katleder, tecavüz eder ve yıkar", " Ellerine bir güç geçtiği zaman içindeki bu dürtüler birden harekete geçer" değerlendirmelerinde bulunmuştur (The New York Times, 26 Şubat 1922: 91).

Diğer taraftan Cardashian, Türkiye'deki misyonerleri de şiddetle eleştirmiştir. O, misyonerlerin en büyük hatasının sadece misyonerlik faaliyetlerine odaklanmak olduğunu söylemiş̧ir. Ermeniler lehine çözüm için çaba göstermediklerini ifade etmiştir. Onların etkisi ile Amerika'nın Türkiye'ye savaş ilan etmekten vazgeçtiği, ortak manda fikrine yöneldiğini, belirtmiştir (The New York Times, 1 Ağustos 1921, s.10)

Cardashian ilerleyen tarihlerde de benzer eleştirilerini dile getirmiştir. O, 26 Şubat 1922 tarihli bir yazısında misyonerlerin en büyük hatasının Ermeni mandasının kurulmasını engellemek olduğu görüşünü tekrar etmiştir. Onun ifadesine göre Misyonerler, Türkiye, Ermenistan, Trans-Kafkasya ve Kürdistan'1 içine alan bir Amerikan mandası fikrini desteklemişlerdir. Oysa bu fikir mantıklı değildir. Aynı zamanda Amerika'ya çok ciddi bir mali yük de getirecektir (The New York Times, 26 Şubat 1922: 91)

Amerika'daki Ermeni Milli Komitesinin başkanı Miran Sevasly ${ }^{11} 1919$ yılı Mart ayından itibaren manda konusundaki görüşlerini kamuoyu ile paylaşmaya başlamıştır. O, Ermenilerin isteğinin ABD yönetiminde manda sistemi kurulması olduğunu açıklamıştır. Ermenistan'daki, Avrupa'daki ve Amerika' daki Ermenilerin aynı beklenti içinde olduğunu ifade etmiştir. Mandater devletlerin ortak görüşünü kabul edeceklerini belirtmekle beraber herhangi bir Avrupa ülkesinin yönetimi altında manda istemediklerini de vurgulamıştır (Detroit Free Press, 6 Mart 1919: 9)

Sevasly basında yer alan başka bir demecinde de Henry Morgenthau'nun ortak manda öneren açıklamalarını eleştirmiştir. O, ABD'nin sadece Ermenistan'ı içine alan bir manda kurması gerektiğini ifade etmiştir. Birleşik Devletlerin Anadolu'yu da bu yolla kontrol edebileceğini belirtmiştir (The Detroit Free Press, 25 Mayıs 1919: 1).

Sevasly açıklamalarında Ermenilerin Ermeni ve Türk ortak mandasını arzu etmediklerini özellikle vurgulamıştır (Boston Globe, 20 Temmuz 1919: 13; Los Angeles Times, 20 Temmuz 1919: 13). O, ABD Dışişleri Bakanı William Philip'e Ermeni mandası konusundaki isteklerini de iletmiştir. Buna göre Ermenilerin isteği bağımsız Ermenistan'dır. Bu ülkenin sınırları Kafkaslardan Akdeniz'e kadar uzanmalıdır. Sınırları belirlenmiş Ermenistan Orta Doğu'da barış ve gelişmenin güvencesi olacaktır. Ermeni mandası kesinlikle Türkiye'den ayrı olmalı ve kendi hükümeti ve bayrağı bulunmalıdır (Christian Science Monitor, 22 Temmuz 1919, s.16).

Sevasly bir başka açıklamasında da Ermeni mandası gerçekleşmez ise milletinin Türklerin ve Tatarların insafına terk edilmiş olacağı uyarısında bulunmuştur. Onun ifadesiyle Ermenilere ihanet tarihe dünyadaki özgür ve uygar ulusların işlediği bir suç olarak kaydedilecektir (Los Angeles Times, 28 Ağustos 1919: 17).

Görüldüğü üzere Miran Sevasly de ABD'nin farklı eyaletlerinde yayınlanan gazetelerden yararlanmıştır. O, bu sayede fikirlerini geniş kitlelere duyurarak daha fazla propaganda yapmıştır. Onun demeç verdiği gazetelerden Christian Science Monitor ve Boston Globe gazeteleri

\footnotetext{
${ }^{11}$ Boston'daki etkin Ermenilerden. Paris'deki Ermeni Milli Delegasyonu'nun Amerika'daki temsilcisi. Amerika'daki Ermeni Milli Birliği'nin başkanı. (New York Times, 12 Temmuz 1918: 2.)
} 
Massachusetts eyaletinin Boston şehrinde basılmaktaydı. Detroit Free Press Michigan eyaletinde Detroit şehrinde, Los Angeles Times ise Kaliforniya eyaletinin merkezi olan Los Angeles'ta yayınlanmaktaydı.

Diğer taraftan New York' daki tanınmış Ermeniler, İngiliz Başbakanı LIoyd George'a bir mektup göndermişlerdir. Mektupta Türklere manda yönetimi kurulması konusunda baskı yapılmasını teklif etmişlerdir. Uluslararası bir mutabakatla hem Türkler hem de Ermeniler için ayrı manda yönetimleri kurulması gerektiği düşüncesini dile getirmişler, ortak mandaya karş1 çıkmışlardır. New York Ermenileri Türkler İstanbul'da kaldığı sürece barışın mümkün olmadığını iddia etmişlerdir. Onlara göre Türkiye bitmez tükenmez sorunların kaynağıdır. Tüm dünya Türklerden kaynaklanan olumsuzlukları bilmektedir. Türklerin sözlerine güvenilmemelidir. Belirtildiğine göre mektupta imzası bulunan kişiler arasında New York'un tanınmış Ermenilerinden Dikran Bedikian da bulunmaktadır. Bedikian Ermenistan ve Türkiye'nin rehabilitasyonu için 1.000.000 dolar vermeye hazır olduğunu açıklamıştır (The New York Times, 1 Mart 1920, s.6).

Ortak manda önerisine karşı çıkanlar içerisinde Ermeni kökenli olmayanlar da vardı. Bunlardan ilki ünlü misyoner Stephen S. Wise'dir". Wise bu sebeple "Eski Imparatorluğun Müttefikler Tarafindan Bölünmesi Bir Gerekliliktir” başlıklı bir makale kaleme almıştır.

Stephen Wise bu makalesinde, Dr Gates'in "Tüm Osmanl Amerikan Mandası altına girsin ve Ermeni mandası Ingilizlere bırakılsın" görüşünü anlamakta güçlük çektiğini belirtmiştir. $\mathrm{Bu}$ düşüncelerin Amerika'nın kendi ulusuna karşı sorumluluklarına ve self determinasyon ilkesine ihanet olacağını ifade etmiştir. Wise, "Türkiye'nin bütün olarak kalmasını" savunan Gates ve arkadaşlarının küçük bir kliğin parçası olduklarını iddia etmiştir. Ona göre Gates' in uzun süre kendi memleketinden uzak kalması ve beş yıl süren savaşı yaşaması Amerika'nın hedeflerinden bihaber olmasına yol açmıştır.

Wise, Gates'in bakış açısının sadece Robert Kolejinin tüm şartlar altında eğitime devam etmesi olduğunu vurgulamıştır. Savaş şartlarında okulların açık olmasının bir anlamı olmadığı görüşünü de savunmuştur. Bu süreçte ABD’de Harvard, Yale, Columbia, Princeton, Cornell ve Johns Hopkins gibi üniversitelerin kapanmış olduğunu hatırlatmıştır. O, Üniversitelerin açık kalması adına Türklerle ve Almanlarla işbirliği yapılamayacağını ifade etmiştir.

Wise'e göre Amerika'nın hedeflerinin müttefiklerin yüksek değerleri ile örtüşmektedir. Barış konferansında Müttefikler Türklere topraklarını bir bütün olarak koruma garantisi vermemişlerdir. Türk İmparatorluğunun yönetimi altında acı çeken Müslüman, Hristiyan ve Musevi tüm uluslara kendi geleceklerine karar verme özgürlüğü tanınmıştır.

$\mathrm{Bu}$ yüzden "cesur ve soylu" Ermenilerin Gates'in önerisi ile kaderine terk edilmesi Amerikan idealleri ile örtüşmemektedir. Ermeni mandasının İngilizlere terk edilmesi Ermenileri Yakındoğu oyununda rehin vermek anlamına gelecektir. Bu haksızlıktır. Çünkü Ermeniler Amerika'nın demokrasi idealleri için en ağır bedeli ödemişlerdir.

Stephen Wise, Gates'in Türkiye'nin bölünmesinin ölümcül sonuçlar doğuracağına yönelik görüşlerine de katılmamıştır. $\mathrm{O}$, kim için ölümcül olacağı sorusunu sormuştur. Türkiye'nin bütünlüğünün sonucunun Ermenilere soykırım uygulanması olduğunu iddia etmiş̧tir.

Diğer taraftan Wise, Gates'in Türklere karşı merhametli davranılması talebinin nedenlerini anlamadığını ifade etmiştir. Kendisinin eninde sonunda bağımsızlığını kazanacak olan Ermeniler için Türklere merhametli davranmayacağını bildirmiştir (The New York Times, 13 Haziran 1919: 2).

\footnotetext{
12 Stephen Samuel Wise ( 1874-1949): Amerika'nın en etkili Musevi liderlerindendir. 1907 yılında New York'a gelmiş ve 1907 yılında özgür bir sinagog kurarak Musevi toplum üzerinde etkili olmuştur. Amerika'daki etkili bir Musevi fikir önderi olarak Ermeni sorunu üzerine Amerikan basınında yorumlar yapmıştır. (Grolier Academic Encyclopedia, Grolier International, 1983, (20): 189.)
} 
Amerika Birleşik Devletleri'nin eski Almanya Büyükelçisi ve "American Comiteee for the independence of Armenia" Başkanı James W. Gerard ${ }^{13}$ da ortak mandaya karşı çıkmış, Ermeni mandasına taraftar olmuştur. O, Amerika Birleşik Devletleri'nin neden Ermeni mandasını kabul etmesi gerektiğini üç maddede halinde açıklamıştır. Birinci maddede Ermeni mandasını kabul etmenin Hıristiyan Amerika'nın görevi olduğu belirtilmiştir. Amerika'nın dünyanın ilk Hıristiyan ulusu olan Ermenilerden gelen yardım çağrısına kulak tıkayamayacağı vurgulanmıştır. İkinci maddede Ermenilerin kendi yurdunu kurmak isteyen yaklaşık 16 millet içinde en fazla acı çekeni olduğu hatırlatılmıştır. Üçüncü maddede ise Amerikan idealleri için hiçbir ulusun Ermeniler kadar mücadele etmemiş olduğu iddia edilmiştir.

Gerard'a göre Ermeniler İsveçliler, Kuzey İtalyalılar ve Rumlar gibi Alpine Aryan rrka mensupturlar. 3000 yıl önce Anadolu'ya gelmişler ve Asyalı fetihçilerin batıya girişlerini engellemek için bir blok oluşturmuşlardır. Anadolu'da Batı Uygarlığının ve Hıristiyanlığın temsilcisi olmuşlardır. Bu sebeple Amerikan inancını ve uygarlığını taşıyan bu ulusa yardım eli uzatmak zorunluluktur.

Ayrıca Gerard Ermenilerin Türklere karşı direnmelerinden de övgü ile bahsetmiştir. O, Ermenilerin hiçbir yardım almadan 7 ay boyunca Türklere karşı koyduklarını, fakat sonunda ezici Türk ve Alman güçleri ile etkisiz hale getirildiklerini söylemiştir. Ona göre Ermeniler bu başarıyı imanları ve Amerika'ya olan bağlılıkları sayesinde kazanmışlardır. Bu nedenle ABD "imanlı Hıristiyan" Ermenilere bağımsızlıklarını sağlama noktasında her türlü yardımı yapmalıdır.

Bütün bunlardan dolayı Gerard, ABD için Ermeni mandasını en sağlam ve cazip mandaterlik olarak görmüştür. Diğer manda yönetimleri ile kıyaslandığında Ermeni mandasının dünya barışına daha fazla huzur ve güven getireceğini iddia etmiştir.

Gerard söz konusu beyanatında Amerikan kamuoyunda Amerika Birleşik Devletleri'nin Anadolu'yu da içine alan bir Ermeni mandasını kabul etmemesi halinde Türklerin Ermenileri rahatsız edecekleri yönündeki görüşü de değerlendirmiştir. $O$, bu görüşün önyargı taşıdığını ifade etmiş̧tir. Ona göre aynı endişe 1878 Berlin Anlaşması döneminde Bulgaristan için de söz konusu edilmişti. Fakat, sonunda Türklerin bu dönemde Bulgaristan'la ilgili hiçbir etkisi olmadığ görülmüştür. Aynı şekilde Ermenilere baskı uygulayacakları korkusu da yersizdir. Bunun iki sebebi vardır. Birincisi Paris Barış Konferansı Türklerin askeri gücünü tıpkı Almanya ve Avusturya'da olduğu gibi sınırlandıracaktır. İkincisi Türkler Ermeniler kadar güçlü bir ordu oluşturamaz. Bir silahlı Ermeni iki Türk askerine bedeldir ${ }^{14}$. Amerikalılar Ermenilerin kendilerini koruyacakları ve organize olacaklarından endişe duymamalıdır. İlaveten Türkler Ermenilere saldıracak olurlarsa Milletler Cemiyeti'nin bu saldırıyı kendisine yapılmış gibi telakki ederek Ermenilere yardım edeceği gözden uzak tutulmamalıdır.

Gerard'a göre Ermeni mandası Birleşik Devletlere herhangi bir askeri yük de getirmeyecektir. Zira Ermeniler devletlerinin kurulması ve topraklarının kontrol altına alınmasını takiben 75.000 kişilik bir ordu kurabileceklerdir. Zira Barış Konferansında " Birleşik Ermenistan" temsilcisi Kafkasya genelinde Rus ordusunda 75.000 Ermeni'nin görev yaptı̆̆ını açıklamıştır. Sadece bu askerler Ermenistan'a getirilmiş olsa bile Ermeni ordusu kurulmuş olacaktır. Bu ordu Amerika'nın mühimmat desteği ile kolayca ülkesini savunabilecektir.

Gerard beyanatında Ermenistan'da Ermeni nüfusun azınlıkta kalacağı iddialarına da cevap vermiştir. $\mathrm{Bu}$ anlamda öncelikle coğrafi olarak Birleşik Ermenistan'ın \%65'inin Türkiye'den ayrılacak topraklardan oluşacağını hatırlatmıştır. O, Ermenistan olarak düşünülen bölgede Ermeni nüfusunun çoğunluk olduğunu iddia etmiştir.

\footnotetext{
13 1913-1917 yılları arasında Amerikan Birleşik Devletleri'nin Almanya Büyükelçiliğini yapmıştır. Ermenilerin en büyük destekçilerindendir. (The Lincoln Daily Star, 9 Mart 1918: 8).

${ }^{14}$ Gerard Ermenilerin Türklerden daha savaşçı bir millet olduğunu iddia etmiştir. Oysa bu iddianın abartılı ve sübjektif olduğu, propaganda amacı taşıdığı açıktır.
} 
Gerard'ın Anadolu'daki Ermeni bölgeleri için 1914 yılına dair verdiği nüfus bilgileri ise şöyledir: Ermeniler 1.403.000, Türkler 943.000, Kürtler ise 482.000'dir. Onun ifadesiyle Kafkas Ermenistan'1, Türkiye'nin diğer bölgelerindeki Ermeniler ve Rus Ermenileri de eklenince nüfusa 1.000.000 daha ilave edilmiş olacaktır. Bunun yanında bağımsız Ermenistan kurulduğunda Türkiye'den zorla gönderilen Sirplar, Bulgarlar ve Rumlar gibi Türkler de bu bölgeyi terk edecektir ${ }^{15}$.

Görüldüğü üzere yazısında sık sık Amerikan değerlerinden demokrasiden, insan haklarından söz eden Gerard, konu Türkler olunca bütün bu söylediklerini çabucak unutmaktadır. Sözde Ermenistan'daki Türklerin zorla evlerinden yurtlarından sürülmelerini önerebilmektedir.

Diğer taraftan Gerard'a göre Türklerin Ermenileri ortadan kaldırmak istemelerinin asıl sebebi Turancılık siyasetidir. Zira Ermeniler, Anadolu'daki Türklerle beraber sayıları yaklaşık 24.000.000'u bulan diğer Turani ırklar ile Anadolu Türkleri arasında bariyer görevi görmektedir. Türklerin planı Hazar ötesindeki Turanlarla iletişim kurarak Pan-İslamizm propagandası yapmak ve dünyaya hâkim olmaktır. "Birleşik Ermenistan" Türkleri Anadolu'ya sıkıştıracak ve gelecekteki Pan-Turanizm tehlikesini ortadan kaldıracaktır.

Gerard, Ermeni Devleti'nin kurulmasını makinenin parçalarının bir araya getirip çalıştırılmasına benzetmiştir. Eğer bu parçalar planlı bir şekilde yerlerine konulabilirse makine çalışacak ve üretmeye devam edecektir.

Ona göre bazı Amerikalıların savunduğu Ermenistan ve Anadolu arasında “ Ortak manda" yönetimi hiçbir fayda sağlamaz. Zira Anadolu birbiri ile hiç bir alakası olmayan parçalardan oluşmaktadır. Buna karşılık Ermenistan dağları, tepeleri, nehirleri ve yeraltı kaynakları ile ayrı bir coğrafi bütündür ${ }^{16}$. Eğer Ermeni mandası içine Anadolu dahil edilirse birçok Ermeni'nin kendi topraklarına gelmesi engellenecektir. Bu durum Amerika'nın o bölgede daha fazla kalmasını gerektirecektir. Çünkü Türkleri kendilerini yönetebilir hale getirmek mümkün değildir. İlla Anadolu için manda isteniyorsa bir Müslüman ülkenin yönetimine verilmelidir (Gerard, 6 Temmuz 1919: 44).

Eski Büyükelçi James W. Gerard, Amerikan basınına yansıyan bir başka açıklamasında da ortak manda fikrine karşı olduğunu tekrarlamıştır. Gerard düşüncelerinin komitenin üyeleri olan Senator Lodge, Elihu Root, Charles E. Huges ve Nicholas Murray Butler tarafindan da paylaşıldığını özellikle vurgulamıştır.

Gerard'ın ifadesiyle bazı kendini bilmez Amerikalılar ülkelerinin İstanbul, Ermenistan ve Anadolu'yu içine alan bir ortak manda yönetimini kabul etmesi gerektiğini söylemişlerdir. Oysa böyle bir manda yönetiminin kabul edilmesi imkânsızdır. Çünkü ortak manda fikri tamamen Türklerin planı ve programıdır. Bu tasarı Türk yönetimini kuvvetlendirecek ve Pan-Türkizm'i harekete geçirecektir. Anadolu'da Ermeni ırkının ve Hıristiyanlığın ortadan kaldırılmasına yol açacaktır

Gerard bu vesileyle Turanizm tehlikesine yeniden dikkati çekmiştir. O, Türklerin Birinci Dünya Savaşı'na girme nedeninin Turani ırklar ve Kafkasya'daki Tatarlar ile bağ kurmak olduğunu iddia etmiştir. Türklerin bu bağ 1 kurarak Ermeni ırkını ortadan kaldırmayı hedeflediklerini söylemiştir. Ona göre "Ortak Manda” Amerika'nın korumasında Türklere savaş boyunca yapamadıklarını gerçekleştirme firsatını sunacaktır. Türkler bu sayede Kafkaslardaki soydaşları ile iletişime geçerek 24.000.000 Turani nüfusu yönlendirebilecektir. Bu da İslam dünyasını kuvvetlendirirken Hıristiyanların sonu olacaktır.

Büyükelçi Gerard, Türklerin Kafkaslarla bağlantıya geçmesini engellemenin tek yolunun Karadeniz'den Akdeniz'e uzanan bağımsız bir Ermenistan'ının kurulması olduğunu

\footnotetext{
15 Yazısında Amerikan değerlerinden demokrasiden, insan haklarından söz eden Gerard sözde Ermenistan'daki Türklerin zorla bölgeden sürülmelerini önermiş olması ilginçtir. Türklere olan bakış açısının ön yargılı ve düşmanca olduğunu göstermektedir.

${ }^{16}$ Oysa coğrafi olarak Anadolu Karadeniz, Akdeniz ve Eğe denizi arasında bulunan yarımadadır. Bir bütünlük teşkil etmektedir.
} 
savunmuş̧tur. O, “Ermeni Yurdu”nun Pan-Türkist yayılmacıllğı frenleyeceği ve bir bariyer oluşturacağı düşüncesindedir.

Ona göre bu yüzden yapılacak ilk iş Ermenistan Cumhuriyetini tanımaktır. Bu yolla açlık çeken milyonlara yiyecek ve giyecek temin etmek mümkün olacaktır. Ayrıca bu teşebbüs neticesinde Ermenistan'ın güney batısını ele geçirmek için zemin hazırlanacaktır. Türklere katliamlar sonunda elde ettikleri çoğunluğu kullanma firsatı verilmemelidir. Sığınmacıların yurtlarına dönmelerini sağlamak Amerika'nın öncelikli görevi olmalıdır. Bununla birlikte Türkler Ermeni yönetimi altına girmek istemiyorlarsa Anadolu'ya göç edebilirler.

Diğer taraftan Gerard, Avrupalıları samimi davranmamakla suçlamış, onların amacının Ermeni mandasının sorumluluğunu Amerika'ya yükleyerek zenginleşmek olduğunu ifade etmiştir. (Detroit Free Press, 8 Aralık 1919:.1, 17).

Los Angeles Times gazetesinde Amerika Birleşik Devletleri'nin müttefikler tarafından kendisine dayatılan Anadolu'yu da içine alan manda yönetimini kabul etmemesi gerektiği üzerinde duran bir yazı kaleme alınmıştır. Yazı gazetenin okurlar köşesinde yayınlanmıştır. Yazarı belli değildir.

Yazıda "Amerikan halk Anadolu ve Karadeniz' i içine alan bir polis görevini kabul etmeli midir?" ve "Sorumluluklarımız böyle bir görevi yerine getirmeyi içerir mi??" soruları okuyucuya yöneltilmiştir. İlaveten Harbert Hoover'ın Amerika'nın dünyada barışçı düzen yaratmak için Türkiye mandasını kabul etmesi gerekliliğine işaret eden görüşü eleştirilmiştir. Amerika'nın Anadolu'yu içine alan ve müttefikler tarafından dayatılan manda yönetimi önerisini iki kere düşünmesi gerektiği ifade edilmiştir.

Makalede Türklerin Ermenilerden nefret ettiği, Ermenilerin de nefretin yeşerdiği bu topraklara geri dönmeye çalıştıkları ifade edilmiştir. Manda yönetiminin en zor işinin birbirini boğazlamakta olan Türkler ve Ermenileri yatıştırmak olacağı hatırlatılmıştır. ABD'nin eski dünyanın birbirinden nefret eden iki ırkının olduğu bölgeye polislik yapmaya davet edildiği vurgulanmıştır. Aslında bu düşmanlığı yaratanların birbirlerine güvenmeyen ve kıskanan Avrupalı hükümdarlar ve hanedanlıklar olduğu belirtilmiştir.

Yazara göre Amerika, dünyaya bir düzen getirecekse buna kendisine yakın bölgelerden başlamalıdır. Oysa ABD'nin Meksika üzerinde etkin olması engellenmektedir. Eğer ABD dünyanın barış içinde bir düzene kavuşması yolunda adım atacaksa Rio Grande nehrinin ötesine yönelmeli, kendisine yakın olan Meksika'nın sorunları ile ilgilenmelidir. Buna rağmen garip bir şekilde Anadolu'da Amerika'nın kontrolünde bir manda yönetimi ısrarla istenmektedir. Bu durum üzerinde durulması gereken bir husustur. Ekonomik olarak Amerika kaybetmektedir. ABD'li iş adamları Türk İmparatorluğunun "etsiz kemiklerine" razı olmak zorunda bırakılmışlardır. Zira Fransa Adana'nın pamuk üretimi yapılan bölgelerini almıştır. Yunanistan, İzmir'in incirini, zeytinyağını, şaraplarını ele geçirmiştir. İngiltere, Mezopotamya'nın tahıllarını, madenlerini ve minerallerini kontrol etmektedir. Amerika Birleşik Devletleri'ne düşen ise zaten paylaşılmış olan bu bölgenin doğal kaynaklarını Türk kuvvetlerinin saldırılarından korumaktır. Bu adil bir paylaşım değildir. Bu yüzden hiçbir Amerikan hükümeti Anadolu'nun paylaşılmış kalıntıları üzerinde manda yönetimini kabul etmemelidir. Eski nefretler ve düşmanlık üzerine kurulu Anadolu'da hiçbir sorumluluğu üzerine almamalıdır. ABD'li diplomatların yeterince bilgi sahibi olmadıkları Türkler, Yunanlılar, Suriyeliler, Ermeniler ile ilgili taahhütlere girmeleri anlamsizdir. (Los Angeles Times, 12 Ocak 1920, s.4).

The National Tribune gazetesinde çıkan bir haberde ise Amerika Birleşik Devletleri'nin yönetiminde Ermeni mandasının Türkiye'yi de içine almasının Türklerin eski bir oyunu olduğu iddia edilmiştir. Tüm dünyanın kendilerini boğazlardan atmak istediğini bilen Türklerin orada kalarak büyük bir gerilim yarattığı belirtilmiştir. Buna göre Türkler, Fransızlara karşı İngilizleri; İngilizlere karşı Rusları; Almanlara karşı diğer ulusları kullanarak Osmanlı İmparatorluğunun 
devamlılı̆̆ını sağlamışlardır. Şimdi de ABD mandası altına girerek toprak bütünlüklerini sağlamaya çalışmaktadırlar.

Haberde belirtildiğine göre Hıristiyanları Türklerin yönetimine vermek ya da Türkleri Hıristiyanların yönetimine bırakmak adil değildir. Böyle bir uygulama sonu gelmez savaşların kaynağı olacaktır. Aya Sofya'da yükselen minareler Yakındoğu'da kalıcı bir barış sağlamayacaktır. Ayrıca müttefiklerin kendi aralarında yaptıkları gizli anlaşmalar sonucunda çıkarlarına göre Türkiye'yi bölmeleri ortaya çıkacak savaşların temel kaynağı olacaktır.

Oysa farklı kabileler, dinler ve fraksiyonların tümü Amerika Birleşik Devletleri'ne güven duymaktadır. Ermeni mandasını kabul edecek tek devlet ABD'dir. Ayrıca Amerika'nın tüm rrklara ve dinsel guruplara sağladığı adalet, onlara yönelik uygulanacak mezalimin engelleneceği güvenini sağlıyor. (The National Tribune, 25 Aralık 1919, s.19).

Ernest Riggs ${ }^{17}$ de ortak mandaya karşı çıkmıştır. Ona göre Ermenilere "Türk kardeşleri" ile beraber manda önerilmesi anlamsızdır. Ancak Ermeni mandası kabul edilmelidir. Yüksek maliyetli olacağı düşüncesi ile Ermenilere yardım etmemek ve yeni bir gelecek kurmalarına katk1 sağlamamak Amerika'ya yakışmayacaktır (Ernest W. Riggs, 1920: 14).

İndianapolis'de görevli Piskopos H.H. Fout da manda meselesi konusunda basina bir açıklama yapmıştır. Bu kişi aynı zamanda American Commission for Relief in the Near East'de de görevli idi. Piskopos açıklamasında Türklerin Ermenilere yaptığı zulüm ve katliamlardan da bahsetmiştir. Onun farklı bilgilere dayanarak ulaştığı sonuca göre savaş başladığında 3.000.000 olan Ermeni nüfusunun 1.000.000'u Türklerin soykırımına maruz kalmıştır. Piskopos kalanların durumunun da içler acısı olduğunu vurgulamıştır.

Ona göre Türkler insanlık onuruna aykırı uygulamalarından dolayı, kendi kendini yönetme hakkını kaybetmiştir. Türklerin, Ermenilerin ve Suriyelilerin Amerika'dan beklentileri çok yüksektir. Türkler Amerika'nın desteği için adeta yalvarmakta, manda altına girmeyi gönülden istemektedirler (The New York Times, 7 Haziran 1919: 6).

Bununla birlikte ilerleyen tarihlerde Kilikya'nın Türkiye'ye bırakılması ABD'ndeki bazı çevrelerde rahatsızlık yaratmıştır. Ermenilerin Bağımsızlığı İçin Amerikan Komitesi'nin Genel Sekreteri Jessup, Yale Kulübü'nde yapılan toplantıda Kilikya'nın Türkiye'ye bırakılmasını eleştirmiştir. O, Milletler Cemiyeti kararları uyarınca Kilikya'da bir Fransız manda yönetiminin kurulacağı beklenirken bu bölgenin tekrar Türklere verilmiş olmasının büyük bir hata olduğunu ifade etmiştir (The New York Times, 7 Ocak 1923: 3).

\section{Sonuç ve Öneriler}

Amerikan basınında Türk-Ermeni ortak mandasını sadece Ermeni asıllı olmayan Amerikalılar tarafindan savunulmuştur. Bunlar içerisinde İstanbul'daki Robert Koleji Müdürü Dr. Caleb Gates ilk sırada yer almaktadır. Bunun dışında ABD'nin eski İstanbul Büyükelçisi Henry Morgenthau da ortak manda yönetiminden yanadır. Yine Chicago Üniversitesi Rektörü Harry Pratt, Misyoner Henry Riggs, Djevad Eyour, Pietro Rizzo ve Harbert Hoover de bu görüşü desteklemişlerdir. Ancak, Türk-Ermeni ortak mandasını destekleyen tek bir Ermeni aydın veya yazar mevcut değildir. Ermenilerin tamamı Amerikan kamuoyuna sadece Ermeni mandası kurulması görüşünü empoze etmeye çalışmışlardır.

Bununla birlikte kısıtlı sayıdaki ortak manda taraftarlarına karşı basında yoğun eleştiriler yöneltilmiştir. Eleştiride bulunanlar içerisinde Ermeni kökenliler olduğu gibi Ermeni olmayanlar da vardır.

\footnotetext{
17 Türkiye'deki ünlü misyonerlerden Henry Riggs'in kardeşidir. 1910 yılında Henry Riggs'in Amerika'ya geri dönmesinden sonra Harput Amerikan Koleji Başkanlığına atanmıştır. 1910-1915 yılları arasında kolej başkanlığı görevini yürütmüştür. Harput’taki son Amerikan misyoner başkanı olmuştur. (Kılıç, 2007:480).
} 
Ortak manda fikrine basın aracıllı̆ı̆yla karşı çıkan Ermeni kökenliler arasında Arshag Mahdesian, Miran Sevasly, Vahan Cardashian ve Dikran Bedikian zikredilebilir. Ermeni olmayan ancak ortak mandayı eleştiren ABD'li aydın ve gazeteciler ise şunlardır: Misyoner Stephen S. Wise, Ernest Riggs, Amerikan Komitesi genel sekreteri Jessup, Piskopos H.H. Fout, Amerika Birleşik Devletleri'nin Almanya Eski Büyükelçi James W.Gerard.

ABD basınında yer alan yayınlar değerlendirildiğinde ortak manda fikrini dile getirenlerin görüşleri özetle şöyledir. Onlar sadece Ermeni mandası kabul edilirse arzu edilen barış ortamının oluşturulamayacağı endişesini dile getirmişlerdir. Onlara göre Türkler kendilerini dışlanmış hissederek batı dünyasından uzaklaşacaklar, nüfus üstünlüklerini kullanarak Ermeniler için tehdit oluşturacaklardır. Anadolu manda altına alınmaz ve Türklerin bağımsızlığı devam ettirilirse bölgedeki diğer milletler huzur bulamayacaklardır. Hıristiyan uygarlığının güvenliği için Anadolu mutlaka kontrol altına alınmalıdır.

Bununla birlikte sadece Ermenistan mandasını kabul etmek her bakımdan ağır bir yük altına girmek demektir. Zira Ermeniler için manda kurulması düşünülen coğrafyada Türklerin ve Müslümanların ezici nüfus üstünlükleri vardır. Ermenistan'ı koruyabilmek için büyük bir orduya ve paraya ihtiyaç olacaktır. Ayrıca Ermenilerin öç alma duygusu ile hareket etmeleri mümkündür. Müslümanların Hıristiyanlara veya Hıristiyanların Müslümanlara yönelik mezalimi ortak manda ve Amerikan adaleti ile engellenebilir.

Ortak manda fikrine karşı çıkanlar ise öncelikle Ermenilerin tarih boyunca Hıristiyan dünyaya yaptığı hizmetlere dikkati çekmişlerdir. Ermeniler için "dünyanın ilk Hıristiyan ulusu" ifadesini kullanmışlardır. Onların Türklerin işgallerine karşı direndiklerini ve müttefiklerle iş birliği içerisinde çalıştıklarını hatırlatmışlardır. Ortak mandanın "kasap ile kuzunun" bir arada yaşaması anlamına geleceğini ifade etmişlerdir. Türkler ile Ermenilerin hiçbir ortak önü olmadığını, milli kalkınmalarını sağlayabilmeleri için mutlaka birbirlerinden ayrılmaları gerektiğini belirtmişlerdir.

Onlar Türkleri medeniyete hiçbir katkıları olmamış, saldırgan bir ulus olarak değerlendirmişlerdir. Bu sebeple Amerikalıların Türkleri, Türklerin de Amerikalıları anlayamayacağını iddia etmişlerdir. Onlara göre Türkler için en uygun mandater devlet İran'dır. Türklerin manda istemeleri iki sebebe dayanmaktadır. Birincisi "Ermenistan topraklarını" ellerinde tutmak, ikincisi ise maddi kazanç elde etmektir.

Ortak manda karşıtları Ermenistan mandası hususunda dezavantaj olarak ortaya konulan nüfus ve güvenlik meselelerine de kendilerince çözüm bulmuşlardır. Onlara göre Ermenilere ayrılan bölgelerdeki Türkler göç ettirilerek Ermeni nüfus çoğunluğu sağlanacaktır. Rus ordusunda bulunan 75.000 Ermeni asıllı asker Ermenistan'a getirildiğinde güvenlik problemi de çözülmüş olacaktır. Onlar Ermeni mandası sayesinde Türklerin Anadolu'ya sıkıştırarak Pan-Turanizm tehlikesini ortadan kaldıracağını da iddia etmişlerdir.

Diğer taraftan özellikle Ermeni kökenlilerin propagandalarını etkin kılabilmek ve yaygınlaştırabilmek için farklı eyaletlerdeki gazetelerde benzer yazılar yayınlattıkları görülmüştür. Onların olumsuz propagandaları bütün Amerikan kamuoyunu etkilemiştir. Asılsız haberler ve bilgilerle gerçekleştirilen kara propagandanın kamuoyu üzerinde ne kadar büyük etkiler yarattığ 1 somut bir şekilde görülmüştür. Nitekim ortak mandayı savunanlar dahi Türkleri zalim ve yıkıcı olarak değerlendirmişlerdir. Ermenileri Türklerin zulmünden koruyabilmek endişesi ile bu görüşü savunmuşlardır. 


\section{Kaynakça}

Akbıyık, Y. (1999). Milli Mücadele'de Güney Cephesi, Ankara: Atatürk Araştırma Merkez Başkanlığı Yayınları.

Akgün, S. (1981). General Harbord'un Anadolu Gezisi ve Ermeni Meselesi'ne Dair Raporu, Kurtuluş Savaşı Başlangıcında, İstanbul: Kervan Kitapçılık.

American National Biography, https://www.anb.org (Erişim tarihi: 20 Nisan 2019).

Ayışı̆̆ı, M. (2004). Kurtuluş Savaşı Strasında Türkiye'ye Gelen Amerikan Heyetleri, Ankara: Türk Tarih Kurumu Yayınları.

Aytepe, O. (Kasım 1999-2003). Milli Mücadele'de Manda Sorunu ve Mustafa Kemal'in Yaklaşımı, Ankara Üniversitesi Türk İnkılap Tarihi Atatürk Yolu Dergisi, (24): 475-486.

Boston Daily Globe.

Christian Science Monitor.

Denk, E. (Nisan 2018). Milletler Cemiyeti Misakı, www.erdemdenk.com/mcmisaki.doc (Erişim tarihi: 20 Nisan 2018).

Detroit Free Press.

Eyour, Djevad, Opportunities for U.S in Near East, The New York Times, 13 Haziran 1922.

Gerard, James W, (1919). Why America Should Accept Mandate For Armenia, The New York Times, 44.

Grolier Academic Encyclopedia, grolier international, (1983), (.20). 189.

Gürbüz, V. (2002). Bir İdeal, Bir Amerikan Başkanı ve Onun Başarısızlığı: Başkan Wilson ve Milletler Cemiyeti, Ankara Üniversitesi Türk Inkılap Tarihi Atatürk Yolu Dergisi, (29-30): 8799.

İlter, E. (2001). Ermeni İstekleri Karşısında Milli Teşekküllerin Tutumu (1919-1922), Ankara Üniversitesi Türk Inkılap Tarihi Atatürk Yolu Dergisi, (27-28): 299-319.

Karacagil, Ö. K. (Yaz 2015). Amerika'da Tek Kişilik Lobi: Vahan Cardashian (1883-1934), Gazi Akademik Bakış Dergisi, 8(16): 95-120.

Kılıç, O. (2007). Kendi Yazdıkları Işı ğında Amerikalı Misyonerlerin Harput'daki Faaliyetleri, Journal of Islamic Research, 20(4):476-491.

Köse, İ. (2014). Woodrow Wilson'un Ermeni Hamiliği Teşebbüsü ve Ermenistan Görevine Giden General Harbord Askeri Kurulu, Türk Dünyası Araştırmaları, 108(212): 53-88.

Köse, İ. (2014). General Moseley'in Amerikan Mandası ve Anadolu'da Kurulması Planlanan Ermeni Devleti ile İlgili Raporu, Tarih Dergisi, (59): 189-216.

Lincoln Daily Star.

Los Angeles Times.

Mahdesian, A. (1917). Armenia, Her Culture and Aspirations, The Journal of Race Development, 7(4): 448-466.

Mahdesian, A. (1919), Recent Suggestions for Armenia, The New York Times, 8 Haziran

Morgenthau, H. (2003). Ambassador Morgenthau's Story, Michigan: Wayne State University Press.

National Tribune. 
New York Times.

Riggs, Ernest W, (1920). Mr. Bryan and Armenia, The New York Times, 14.

Washington Star. 